\title{
PReS-FINAL-2101: Nitrous oxide analgesia for intra-articular injection in juvenile idiopathic arthritis: our experience
}

\author{
S Pastore ${ }^{*^{*}}, V_{\text {Moressa' }}^{1}, \mathrm{G}$ Gortani $^{2}$, L Lepore ${ }^{2}$ \\ From 20th Pediatric Rheumatology European Society (PReS) Congress \\ Ljubljana, Slovenia. 25-29 September 2013
}

\section{Introduction}

Nitrous Oxide (NO), known as "laughing gas", is a volatile gas with analgesic, anxiolytic and sedative properties, used for treatment of short-lived mild or moderate pain.

\section{Objectives}

To evaluate the efficacy and safety of nitrous oxide-oxygen for children with juvenile idiopathic arthritis (JIA) undergoing intra-articular corticosteroid injection.

\section{Methods}

A 50:50 mixture with $\mathrm{NO}$ and oxygen was administered to JIA patients over the age of 5 years scheduled for joint injection. In some cases additional sedative agents (local EMLA, orally midazolam, nasal fentanest) was administered. Every patient completed visual-analogue scores (VAS) (0-10) for pain immediately after the procedure, and after 30 and 60 minutes. The physician valuated sedation level according to Ramsay scale and memory level of the procedure.

\section{Results}

A total of 31 joints were injected in 25 patients $(23 \mathrm{~F}, 2 \mathrm{M}$, median age 10.4 years). EMLA was placed in all patients at least one hour before the procedure. 19/25 patients received oral midazolam $(0.5 \mathrm{mg} / \mathrm{kg}) 30$ minutes before the intra-articular injection. $1 / 25$ patients received nasal fentanest $(75 \gamma)$ during the procedure. The median pain score for patient $(0-10 \mathrm{~cm}$ VAS) was 0.7 immediately after the procedure, 0.6 after 30 minutes, and 0.5 after 60 minutes. Only 3 out of 25 patients remembered the procedure. There were no adverse events in any patient.

${ }^{1}$ University of Trieste, Trieste, Italy

Full list of author information is available at the end of the article

\section{Conclusion}

Nitrous oxide-oxygen provides safe and effective analgesia for JIA children undergoing intra-articular injections, avoiding intravenous cannulation and general anaesthesia.

\section{Disclosure of interest}

None declared.

Authors' details

${ }^{1}$ University of Trieste, Trieste, Italy. ${ }^{2}$ Institute for Maternal and Child Health IRCCS "Burlo Garofolo", Trieste, Italy.

Published: 5 December 2013

doi:10.1186/1546-0096-11-S2-P113

Cite this article as: Pastore et al:: PReS-FINAL-2101: Nitrous oxide

analgesia for intra-articular injection in juvenile idiopathic arthritis: our experience. Pediatric Rheumatology 2013 11(Suppl 2):P113.
Submit your next manuscript to BioMed Central and take full advantage of:

- Convenient online submission

- Thorough peer review

- No space constraints or color figure charges

- Immediate publication on acceptance

- Inclusion in PubMed, CAS, Scopus and Google Scholar

- Research which is freely available for redistribution
( Biomed Central 